\title{
Effects of mortality changes on biomass and production in Calanus spp. populations
}

\author{
Jofrid Skarðhamar ${ }^{1,2, *}$, Marit Reigstad ${ }^{3}$, JoLynn Carroll $^{2,4}{ }^{,}$Ketil Eiane $^{5}$, \\ Christian Wexels Riser ${ }^{3}$, Dag Slagstad ${ }^{6}$ \\ ${ }^{1}$ Institute of Marine Research, 9294 Tromsø, Norway \\ ${ }^{2}$ Akvaplan-niva, Fram Centre, 9296 Tromsø, Norway \\ ${ }^{3}$ Department of Arctic and Marine Biology, University of Tromsø, 9037 Tromsø, Norway \\ ${ }^{4}$ Department of Geology, University of Tromsø, 9037 Tromsø, Norway \\ ${ }^{5}$ Faculty of Bioscience and Aquaculture, University of Nordland, 8049 Bodø, Norway \\ ${ }^{6}$ SINTEF Fisheries and Aquaculture, 7465 Trondheim, Norway
}

\begin{abstract}
Calanus species are the main link between primary producers and higher trophic-level organisms in the Barents Sea. The natural mortality rate is an essential parameter for determining the standing stock of Calanus, but it is also one of the most uncertain parameters in present knowledge. The level of human activity, and the associated risk of pollution, is increasing in the Barents Sea, and knowledge of the Calanus population response to increased mortality is crucial for management of the ecosystem. In the present study, we estimated natural mortality rates of Calanus, based on available field data from the Barents Sea, and performed numerical simulation experiments with a coupled physical-biological model, testing the response of Calanus populations to changes in mortality rates, and other related ecological parameters. The field-based estimates of natural mortality showed high variability. The model simulations showed that the 2 Calanus species modelled, C. glacialis and C. finmarchicus, respond differently to increased mortality, and that increased mortality alters both the timing of peak Calanus production and biomass relative to peak primary production. These simulations illustrate the potential for a mismatch between peak food availability and Calanus population dynamics in the Barents Sea as a consequence of natural or human-induced perturbations. We suggest that the observed differences in the 2 Calanus species' responses to perturbations relates to each species' life cycle and habitat characteristics. The present study illustrates how models can be used to assess key parameters affecting species' population dynamics and some potential consequence of external forcing factors affecting mortality.
\end{abstract}

KEY WORDS: Zooplankton - Calanus finmarchicus - Calanus glacialis · Numerical modelling · Ecological modelling $\cdot$ Arctic $\cdot$ North Atlantic $\cdot$ Barent Sea $\cdot$ Simulation

\section{INTRODUCTION}

Calanus glacialis and C. finmarchicus are key species in the transfer of energy from phytoplankton to higher trophic-level organisms in the North Atlantic and the Barents Sea (Conover 1988, Falk-Petersen et al. 2009). Their ability to synthesise and store lipids makes them attractive prey items and they are robust survivors in environments characterised by high natural variability in environmental parameters (Falk-
Petersen et al. 1990). In the Barents Sea, C. glacialis is the dominating copepod species in terms of biomass in the Arctic water masses north of the Polar Front, while C. finmarchicus dominates in the Atlantic water masses south of the front. Natural mortality is a key parameter for determining the standing stock of Calanus spp., both after the overwintering season and during the productive season. It is also one of the most uncertain parameters because it is difficult to directly measure or establish by indirect methods (Aksnes \& 
Ohman 1996). Mortality may be the result of natural events driven by, for example, limited food availability or the presence of abundant predatory species, or by human activities, such as pollution. In the Arctic, industrial activities are on the rise. For example in the Barents Sea, petroleum transport from Russia along the Norwegian coastline increased from insignificant volumes in 2002 to an estimated 20 million tons in 2009 (Bambulyak \& Frantzen 2009). Parts of the Barents Sea have already been opened for oil and gas exploration, and the Lofoten and Vesterålen shelves, at the 'entrance' to the Barents Sea, are currently being considered for oil and gas exploration by the Norwegian government. Increasing petroleum transport, oil and gas exploration, and other industrial activities increase the risk of accidents and the potential for negative impacts on individual organisms and ecosystems (Chapman \& Riddle 2003). Understanding Calanus population responses to increased mortality is crucial for management of the Barents Sea ecosystem.

A difference between the 2 Calanus sibling species is their life history. C. glacialis has 2 overwintering seasons while $C$. finmarchicus has only 1 overwintering season before the reproductive stage (Tande 1991, Kaartvedt 1996). C. finmarchicus is a boreal species and its abundance in the Barents Sea strongly depends on the advection of Atlantic water into the Barents Sea. In contrast, C. glacialis overwinters on Arctic shelves including the Barents Sea (Hirche \& Kwasniewski 1997, Falk Petersen et al. 2009), with advection playing a minor role in sustaining population size. Most of the $C$. finmarchicus population overwinter outside the shelf break, west of Norway and the Barents Sea at 700 to 1000 m depth (Østvedt 1955, Halvorsen et al. 2003, Slagstad \& Tande 2007). C. glacialis has slower growth, lower mortality, and larger individuals compared to C. finmarchicus (Scott et al. 2000, Arnkværn et al. 2005). C. finmarchicus and C. glacialis spawn in spring to 'match' the period of enhanced primary production (Conover 1988, Falk-Petersen et al. 2009). The size of the overwintering population of adults is thought to play an important role in the recruitment of the next generation of Calanus, influencing Calanus production and biomass in the following spring season. Variability in production and biomass influences food availability and energy transfer to higher trophic levels of the Barents Sea food web.

The aim of the present study was to investigate the sensitivity of the response of Calanus spp. in the Barents Sea to increased mortality, expressed in terms biomass and production rate, i.e. the resilience of Calanus populations to perturbations characterised by periods of increased acute mortality. To achieve this we performed numerical model experiments simulating Calanus production and biomass. We examined (1) model responses of the Calanus populations to changes in overwintering population size and growthseason population size, (2) variable mortality rate scenarios for Calanus constrained by estimated natural mortality rates and timing of episodically increased mortality, and (3) the sensitivity of Calanus biomass to a simulated increased and prolonged mortality event to represent a simple first-approach simulation of the temporal and spatial impact of a large oil spill (blowout).

\section{MATERIALS AND METHODS}

Estimating natural mortality rates. To quantify patterns in mortality that could be used to constrain variability in scenario modelling, we opted for a simple approach where mortality was estimated separately for 2 periods of the year: the high-productivity season (May through August) and the low-productivity season (September through April). The May through August period roughly corresponds with the period of rapid increase in the number of copepodite stages in Calanus populations in Svalbard waters $\left(78^{\circ} \mathrm{N}\right)$, whereas the rest of the year is characterised by declining copepodite population densities (Arnkværn et al. 2005) in the study area. Note that our data sets do not include the earliest life stages (eggs and nauplii) of Calanus, which could be active before May (e.g. Conover 1988). This is a source of potential bias in our analysis. However, field studies indicate the presence of Calanus nauplii in significant quantities only between early May and late June, with a clear peak in late May (Arnkværn et al. 2005). Calanus mortality for both seasonal periods were computed for 2 regions: the northwestern Barents Sea (based on stage-structured data series presented in Arnkværn et al. 2005, Daase \& Eiane 2007, Daase et al. 2007; in total 36 and 56 data points for the May to August and September to April periods, respectively), and the southeastern Barents Sea based on data from the International Ocean Atlas Series (Vol. 2: Biological Atlas of the Arctic Seas 2000, available at www.nodc.noaa.gov/OC5/BARPLANK/WWW/HTML/ bioatlas.html; 96 and 327 data points for the MayAugust and September-April periods, respectively). These data are from sampling performed in the southeastern Barents Sea $\left(68^{\circ} 12^{\prime}\right.$ to $73^{\circ} 00^{\prime} \mathrm{N}, 33^{\circ} 30^{\prime}$ to $41^{\circ} 20^{\prime} \mathrm{E}$ ), collected from 1952 to 1962 . Sampling was performed by vertical Juday net hauls (mesh size: 168 $\mu \mathrm{m}$, sampling area: $0.11 \mathrm{~m}^{2}$ ).

We have limited our analysis to observations from stations where bottom depth exceeded $100 \mathrm{~m}$. This should reduce noise caused by near-bottom or shore effects that may exist for instance on shallow banks or in estuaries (Mann \& Lazier 2006). 
To estimate mortality rates we applied the vertical life-table method (VLT; Mullin \& Brooks 1970, Aksnes \& Ohman 1996) on relative abundance estimates of copepodite stages of Calanus spp. This method estimates the mortality rate $\left(m, \mathrm{~d}^{-1}\right)$ of a combination of 2 consecutive stages $(i$ and $i+1)$ from the ratio $\left(r_{i}\right)$ of the abundance $\left(n\right.$, ind $\left.\mathrm{m}^{-3}\right)$ of the 2 stages $\left(n_{i}, n_{i}+1\right)$ and the stage duration $(D)$ of the 2 stages $\left(D_{i}, D_{i+1}\right)$ by solving

$$
r_{i}=\frac{e^{\left(m D_{i}-1\right)}}{1-e^{\left(m D_{i}+1\right)}}
$$

(for $m$ by iteration) for the combination of 2 juvenile stages, and

$$
m=\frac{\ln \left(r_{i}+1\right)}{D_{i}}
$$

for the combination of the oldest juvenile stage and the adult stage (Aksnes \& Ohman 1996). As VLT estimation relies on estimates of ratios between stage-specific abundances and not absolute abundance estimates, it is assumed to be relatively robust to variations in abundance associated with advection, as long as the combination of stages under analysis is affected in the same manner (Aksnes et al. 1997). Thus this method is well suited for the open-ocean data sets used here. To limit variance caused by small-scale patchiness in copepod abundance we limited our analysis to data points that contained at least 50 individuals (assuming a mean

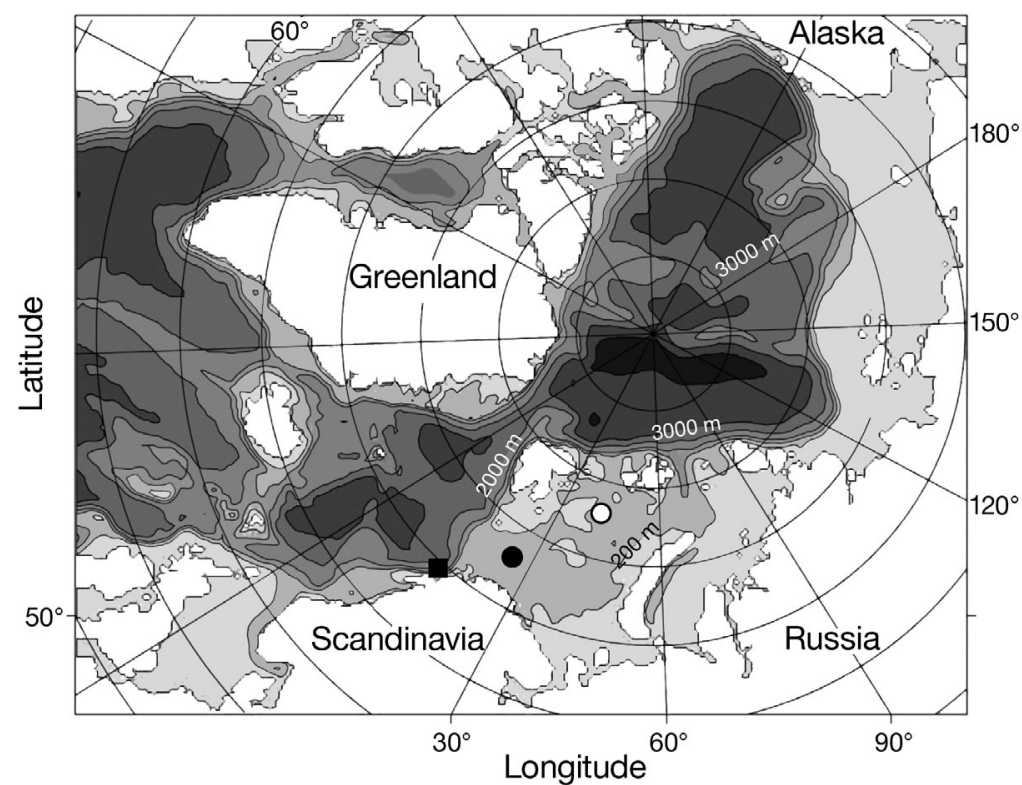

Fig. 1. Bathymetry map of the model area for SINMOD with grid cell distance of $20 \mathrm{~km}$. The circles denote the Atlantic (-) and Arctic (O) grid cells providing input to the 1-dimensional ecosystem simulations. The location on the Norwegian shelf with increased mortality in the 3-dimensional simulation is also shown ( $\mathbf{\square}$. Isobaths are for depths 200, 500, 1000, 2000, 3000 and $4000 \mathrm{~m}$, darkest areas are $>4000 \mathrm{~m}$ sampling volume of $17.8 \mathrm{~m}^{3}$ ) of each stage-pair for which mortality was estimated. In this way we obtained a total of 163,180,202, 258, and 126 mortality estimates for stage-combinations CI-CII, CII-CIII, CIIICIV, CIV-CV, and CV-adult females for C. finmarchicus, and 26, 31, 72, 74, and 47 mortality estimates for the same stage combinations of C. glacialis.

We estimated the duration of developmental stages from the Bêlehràdek temperature function

$$
D=a(T+9.11)^{-2.05}
$$

where $T$ is temperature $\left({ }^{\circ} \mathrm{C}\right)$, and $a$ is a stage-specific constant for which we used the empirically fitted values for Calanus finmarchicus copepodite stages CI to CV obtained by Campbell et al. (2001). Adult stages were assumed to be of infinite duration. To estimate duration of developmental stages of C. glacialis we assumed the temperature-specific conversion function from C. finmarchicus development times given by Arnkværn et al. (2005). To account for increased development time of dormant developmental stages in winter (primarily CV in C. finmarchicus, and CIV and CV in C. glacialis; Conover 1988, Hirche \& Kwasniewski 1997), we increased the temperature-dependent model of stage duration by $150 \mathrm{~d}$. This was chosen as it is the approximate time period for life-cycle closure for a C. finmarchicus $\mathrm{CV}$ active in August to reproduce around 1 March the coming year in these waters (Arnkværn et al. 2005).

Stage-specific mortality estimates for each of these periods were converted into weight-specific rates by the following procedure: for each stage-pair for which mortality rate was estimated, we computed weight-specific mortality by estimating the standing stock biomass for the stage-pair from the abundance data and published size-weight regressions (Mauchline 1998) assuming a medium length value for all stages in the data used in Arnkværn et al. (2005). For each station we computed the weighted average of mortality based on the contribution to total biomass from each stage-pair. Estimated weight-specific mortality was then estimated by averaging over all stations included in each region and seasonal periods. Note that this procedure ignores contributions to total biomass from developmental stages not assigned to a stage-pair (when adjacent developmental stages did not occur in the data).

Model simulations. The model SINMOD is a physical-biological coupled numerical ocean circulation model of the Barents Sea, developed by SINTEF in close cooperation with biologists in Tromsø (Slagstad 1987, Slagstad \& McClimans 2005, Wassmann et al. 2006). 
The model setup used here covers the whole Barents Sea, the Polar Ocean and the Nordic Seas with $20 \mathrm{~km}$ grid cell distance (Fig. 1). The ecosystem part of the model consists of 13 state variables, including nutrients, bacteria, phytoplankton, detritus, dissolved organic carbon, microzooplankton and the 2 mesozooplankton species Calanus finmarchicus and C. glacialis (Fig. 2). The model is nitrogen-driven, and conversion to carbon is according to a constant $\mathrm{C}: \mathrm{N}$ ratio of 7.6 (Reigstad et al. 2008). Each Calanus species is represented by a single compartment biomass model. Calanus feed on diatoms and ciliates and growth of Calanus biomass $\left(B, \mathrm{~g} \mathrm{~cm}^{-2}\right)$ is a function of ingestion rate $\left(I, \mathrm{~d}^{-1}\right)$, excretion rate $\left(E, \mathrm{~d}^{-1}\right)$ and $m$ :

$$
\frac{\mathrm{d} B}{\mathrm{~d} t}=B\left(a_{s} I-E-m\right)
$$

where $a_{S}$ is the assimilation efficiency and $I$ is given by $I=\min \left(I_{\max }, I_{D i a}+I_{M i c}\right)$, and $I_{\max }=C_{o x} \mathrm{e}^{0.063 T}$ is the temperature $(T)$-dependent maximum ingestion rate. $C_{O X}$ is the maximum ingestion rate at $0^{\circ} \mathrm{C}$. $I_{D i a}$ and $I_{M i c}$ are ingestion rates of diatoms and microzooplankton, respectively, using a Holling Type II relationship between ingestion and food concentration (Holling 1959).

Ontogenetic behaviour is simulated by an imposed vertical migration. Overwintering takes place between 500 and $1000 \mathrm{~m}$ depth, or close to bottom in shallower grid cells. Ascent to the surface takes place during March and April. Both species stay in the upper $50 \mathrm{~m}$ of the water column until their descent to the overwintering depth in August. The rate of loss of Calanus finmarchicus and C. glacialis biomass through mortality is 0.75 and $0.2 \% \mathrm{~d}^{-1}$, respectively, for active stages (I. Ellingsen, SINTEF, pers. comm.; Wassmann et al. 2006). The model characteristics are thoroughly docu-

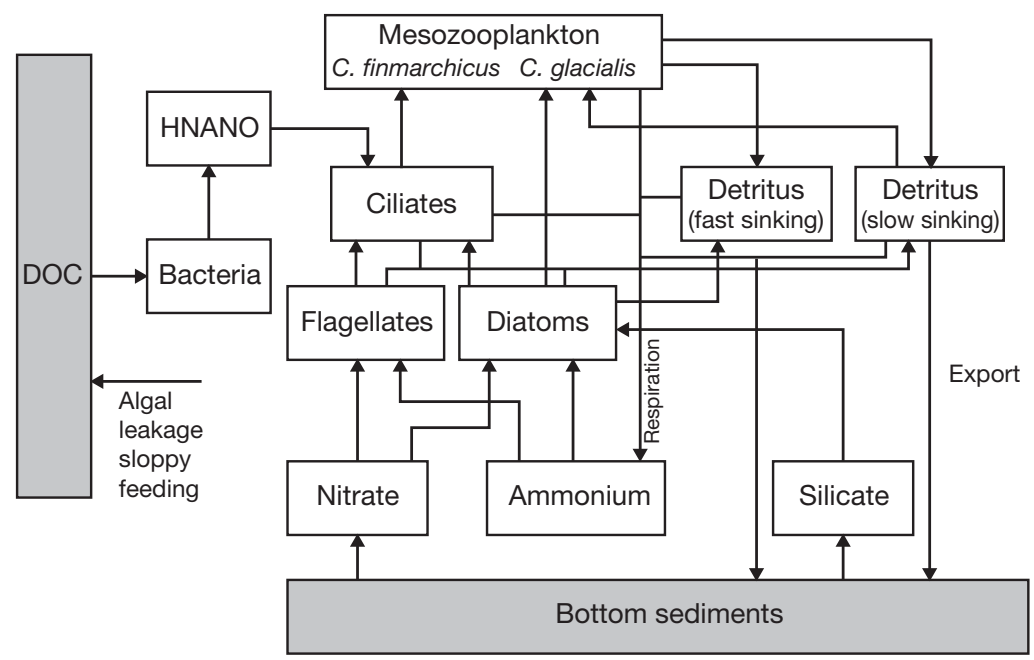

Fig. 2. Structure of the SINMOD ecosystem model. See text ('Materials and methods: Model simulations') and Wassmann et al. (2006) for details. C.: Calanus; DOC: dissolved organic carbon; HNANO: heterotrophic nanoflagellates mented in the scientific literature (e.g. Sakshaug \& Slagstad 1992, Wassmann \& Slagstad 1993, Slagstad et al. 1999, Skarðhamar \& Svendsen 2005, Wassmann et al. 2006, Ellingsen et al. 2008, 2009, Sundfjord et al. 2008, Reigstad et al. 2011).

We performed sensitivity tests on the governing biological parameters: overwintering population size, growth season population size, and mortality rates. These tests were performed using a combination of 1-dimensional (1D) and 3-dimensional (3D) modelling; the ecosystem model was run 1D with input data of physical forcing from the 3D model, which was forced with atmospheric data from the European Centre for Medium-Range Weather Forecasts (ECMWF) operational archive.

We compared simulation results from different sides of the Polar Front in the Barents Sea. The southwestern part of the Barents Sea is dominated by Atlantic water, while Arctic water dominates north and east of the front (Loeng 1991). We therefore refer to these ocean areas as the 'Atlantic' and 'Arctic' parts respectively of the Barents Sea. The 1D simulations were performed for 2 grid cells: 1 cell in the southwestern part of the Barents Sea, representing Atlantic water (Atlantic station) and dominated by Calanus finmarchicus, and 1 cell in the northern Barents Sea, representing Arctic water (Arctic station) with sea ice present, and dominated by C. glacialis (Fig. 1). The simulations of Calanus development spanned 1 productivity season (23 February to 1 November 2005) covering the period of maximum population growth. Output data from the 1D model was temporal development of Calanus production and biomass. Simulations with different perturbations were performed to see how sensitive the 2 Calanus species are to variable stressors. The tests were conducted for both Calanus species, since their different life cycles in the Barents Sea may lead to different patterns of development.

The biological part of the model was run in 1D with physical forcing data from the full-scale 3D model. Input data from the 3D model comprised vertical distribution and temporal variation of temperature (Fig. 3), salinity, vertical mixing, and temporal variation in ice cover and ice thickness. The Atlantic station was ice-free throughout the simulation. The water column here was vertically homogeneous with respect to temperature in winter, while a pronounced thermocline developed in June, before collapsing again in October (Fig. 3). In contrast, the Arctic station was ice-covered for most of the simulated period, with surface temperature near the freezing point throughout 


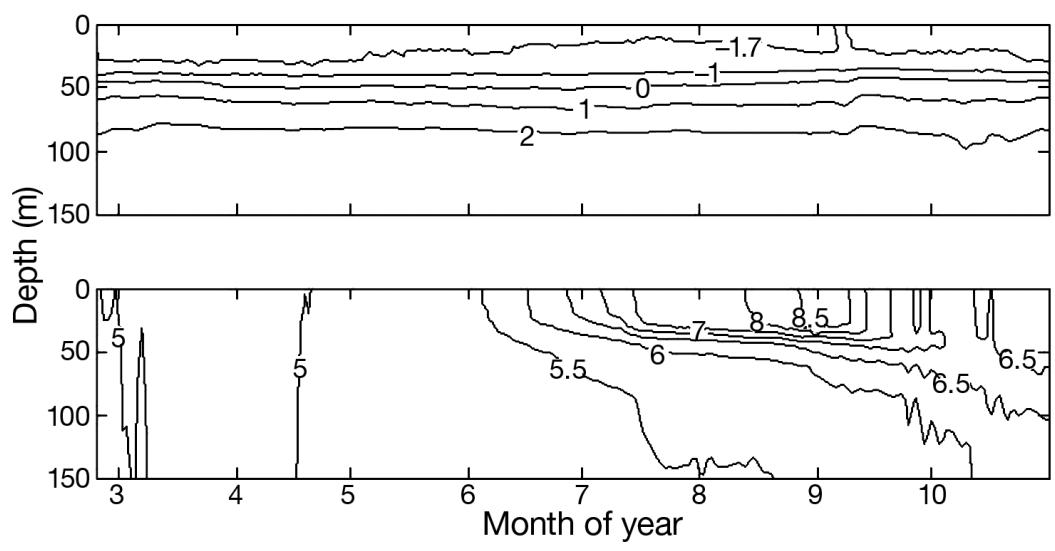

Fig. 3. Modelled temperature $\left({ }^{\circ} \mathrm{C}\right)$ development at the Arctic station (upper) and the Atlantic station (lower paner) in the Barents Sea model domain

(non-overwintering) and $0.15 \% \mathrm{~d}^{-1}$ for hibernating $C$. finmarchicus. Only the mortality rate for active $C$. finmarchicus was adjusted in the model runs. The highest value corresponded to the estimated mortality rates for $C$. finmarchicus obtained from field data (see 'Results: Natural mortality rates and biomass from field data'). Based on the model results from $C$. finmarchicus (see 'Results: Variations in mortality rates'), we elected not to perform similar tests for C. glacialis.

All 1D simulation results were compared with the 'standard' 1D simulation (original model setup) in which the temporal development of Calanus pro-

the simulation. The temperature increased with depth in the upper $200 \mathrm{~m}$, due to impact from deep advected Atlantic water, with minor temporal variability.

$1 D$ model experiments: Overwintering population size: Simulations with different 'start values' of Calanus biomass were performed to address sensitivity of Calanus spp. production and biomass to different overwintering population sizes. The default values in the model are 4 and $2.5 \mathrm{~g} \mathrm{C} \mathrm{m}^{-2}$ for C. finmarchicus and C. glacialis respectively, which are within the ranges reported for the Barents Sea in March and early spring (Tande 1991, Arashkevich et al. 2002) and late autumn (Dalpadado et al. 2003). In our test we chose starting values covering the entire range expected in the Barents Sea. Thus, C. finmarchicus overwintering population size (Atlantic station) was set to 1, 2, 4, 8 and 16 $\mathrm{g} \mathrm{C} \mathrm{m}^{-2}$, and C. glacialis overwintering population size (Arctic station) was set to $0.5,1.5,2.5,3.5,5.0$ and 8.0 $\mathrm{g} \mathrm{C} \mathrm{m} \mathrm{m}^{-2}$ at the beginning of the simulations.

Growth season and population size: Simulations addressed the sensitivity of Calanus finmarchicus biomass to a population size reduction of $50 \%$ (Atlantic station) on 4 different dates. Four simulations were performed, 1 for each date of reduction: 15 May, 1 June, 15 June and 1 July. A complementary sensitivity analysis was performed on C. glacialis biomass for a population size reduction of $50 \%$ (Arctic station) on the dates 1 June, 1 July, 15 July and 1 August. These simulations addressed the sensitivity to timing of episodic mortality increases. The dates were chosen in accordance with each species' temporal development in order to represent perturbations occurring from early growth to peak biomass. Therefore the dates of reduction are different for the 2 species/stations.

Mortality rate: Here we evaluated the sensitivity of Calanus finmarchicus biomass to mortality rates. Mortality rates were set to: $1.5,3.0$ and $4.8 \% \mathrm{~d}^{-1}$. The default value used in the model was $0.75 \% \mathrm{~d}^{-1}$ for active duction rate and biomass were simulated for the period 23 February to 31 October, encompassing the entire productive season. Only 1 factor was changed for each simulation, and possible cumulative effects resulting from interacting responses were not addressed here.

3D model experiment: The 3D model simulations of Calanus development were performed with the model domain shown in Fig. 1, providing a spatial simulation of productivity and biomass dynamics responses to increased and persistent mortality rates. Mortality of C. finmarchicus and C. glacialis was increased to $20 \% \mathrm{~d}^{-1}$ from 1 May to 5 June in 4 grid cells, representing a surface area of $1600 \mathrm{~km}^{2}$, at 2 specific locations. The location in Arctic water masses was the same as the Arctic station in the $1 \mathrm{D}$ experiments (Fig. 1, open circle). The other location was on the Norwegian continental shelf outside Vesterålen (Fig. 1, black square). This location was chosen because it is in the main pathway for $C$. finmarchicus being advected into the Barents Sea from their overwintering sites, as well as being an important feeding area for cod larvae, i.e. the new recruits to the Barents Sea cod stock. It is also an area currently being considered for oil exploration by the Norwegian government. In May and June, the entire copepod population is present in the upper water column, exhibiting minor vertical migration due to the midnight sun (Falkenhaug et al. 1997, Arashkevich et al. 2002, Basedow et al. 2008, Fossheim \& Primicerio 2008).

The scenario with mass mortality was set up to highlight potential spatial and temporal effects of a persistent perturbation. All other components of the ecosystem were unchanged. The relative change in biomass $\left(R_{B}\right)$ caused by the increased mortality rate was defined as:

$$
R_{B}=\frac{B_{\text {new }}-B_{\text {ref }}}{B_{\text {ref }}}
$$


where $B_{\text {new }}$ is the new biomass value caused by the increased mortality rate, and $B_{\text {ref }}$ is the reference value from a model run without an increased mortality rate (i.e. undisturbed system). The relative change $\left(R_{B}\right)$ was computed for each grid cell in the model domain.

\section{RESULTS}

\section{Natural mortality rates and biomass from field data}

Natural variability in Calanus spp. biomass was high in the southeastern Barents Sea (Fig. 4), but a seasonal signal was apparent, with lower levels in early spring (median dry weight for all years lumped was around $0.2 \mathrm{~g} \mathrm{~m}^{-2}$ in April), a clear peak in June and July (ca. $12 \mathrm{~g} \mathrm{~m}^{-2}$ ), and a secondary peak in September (ca. $7 \mathrm{~g}$ $\mathrm{m}^{-2}$ ). In both locations and for both species, the estimated weight-specific mortality rates for use in simulation studies were high (3.3 to $4.8 \% \mathrm{~d}^{-1}$ ) and extremely variable (Table 1). Wintertime values were somewhat lower for C. finmarchicus (1.6 to $\left.2.2 \% \mathrm{~d}^{-1}\right)$, and substantially lower for C. glacialis $\left(0.2 \% \mathrm{~d}^{-1}\right)$.

\section{Model simulations}

\section{Standard model setup}

The simulated seasonal development in Calanus finmarchicus production at the Atlantic station, using standard setup (Fig. 5), shows that $C$. finmarchicus reaches maximum production in late June (Fig. 5b). C. finmarchicus is predominantly herbivorous and utilises the phytoplankton bloom for successful reproduction, but also microzooplankton are of importance (Falk-Petersen et al. 1999, Calbet \& Saiz 2005). The maximum biomass of $C$. finmarchicus is reached $5 \mathrm{~d}$ after the production maximum. There is a reasonably good 'match' between primary producers (Fig. 5a) and C. finmarchicus. A similar pattern is found for C. glacialis at the Arctic station (Fig. 5c). The maximum production rate and biomass of $C$. finmarchicus is higher and is reached earlier than for C. glacialis, but the simulated production of C. glacialis was higher than $C$. finmarchicus from early July and onwards.

\section{Variations in overwintering population} size

Simulations of different overwintering population sizes for Calanus finmarchicus (range: 1 to $16 \mathrm{~g} \mathrm{C} \mathrm{m}^{-2}$; width of range: $15 \mathrm{~g} \mathrm{C} \mathrm{m}^{-2}$ ) produced biomass values of

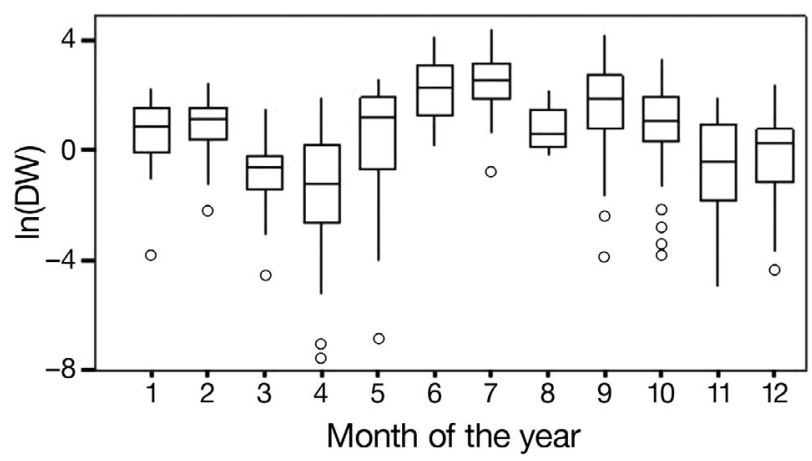

Fig. 4. Calanus finmarchicus and C. glacialis. Seasonal variability (monthly medians, all years combined) in Calanus biomass as ln-transformed dry weight (DW, $\mathrm{mg} \mathrm{m}^{-3}$ ) of all copepodite stages in the southeastern Barents Sea data set (see 'Materials and methods' for details). All data from 1952 to 1962 are combined. Boxes display median \pm 1 quartile; whiskers denote distance to data point furthest away from median provided the distance from the central 2 quartiles is $\leq 1.5$ box height; and open circles denote outliers

2.3 to $4 \mathrm{~g} \mathrm{C} \mathrm{m}^{-2}$ (width of range: $1.7 \mathrm{~g} \mathrm{C} \mathrm{m}^{-2}$ ) at the end of the model run (31 October; Fig. 6). For C. glacialis, overwintering population sizes from 0.5 to $8 \mathrm{~g} \mathrm{C} \mathrm{m}^{-2}$ (width of range: $7.5 \mathrm{~g} \mathrm{C} \mathrm{m}^{-2}$ ) produced biomasses between 2.2 and $7.8 \mathrm{~g} \mathrm{C} \mathrm{m}^{-2}$ (width of range: $5.6 \mathrm{~g} \mathrm{C} \mathrm{m}^{-2}$; Fig. 6).

\section{Reduction of biomass during the productive season}

Scenarios of reduced Calanus finmarchicus biomass between 15 May and 15 June all led to a few days' delay in the timing of peak production and a lowering of the maximum biomass values compared to the standard model setup (Fig. 7). A similar reduction of biomass on 1 July had no effect on the timing because maximum productivity had already been attained before 1 July in the 'standard' simulation. For all simulations, the productivity was slightly higher in July than in the standard run, but the biomass did not recover to the level of the unperturbed simulation. At the end of October, the biomass was between 2.4 and $3 \mathrm{~g} \mathrm{C} \mathrm{m}^{-2}$,

Table 1. Calanus finmarchicus and C. glacialis. Estimated average biomassspecific mortality during 2 periods for the southeastern and northwestern parts of the Barents Sea. Data for C. glacialis was not available for the southeastern Barents Sea

\begin{tabular}{|c|c|c|c|}
\hline \multirow[t]{2}{*}{ Area } & \multirow[t]{2}{*}{ Species } & \multicolumn{2}{|c|}{ Mortality $\left(\% \mathrm{~d}^{-1}\right.$, mean $\left.\pm \mathrm{SD}\right)$} \\
\hline & & May to Aug & Sep to Apr \\
\hline Southeast Barents Sea & C. finmarchicus & $4.8 \pm 6.7$ & $2.2 \pm 2.3$ \\
\hline \multirow[t]{2}{*}{ Northwest Barents Sea } & C. finmarchicus & $3.3 \pm 6.0$ & $1.6 \pm 2.7$ \\
\hline & C. glacialis & $4.4 \pm 5.9$ & $0.2 \pm 0.1$ \\
\hline
\end{tabular}



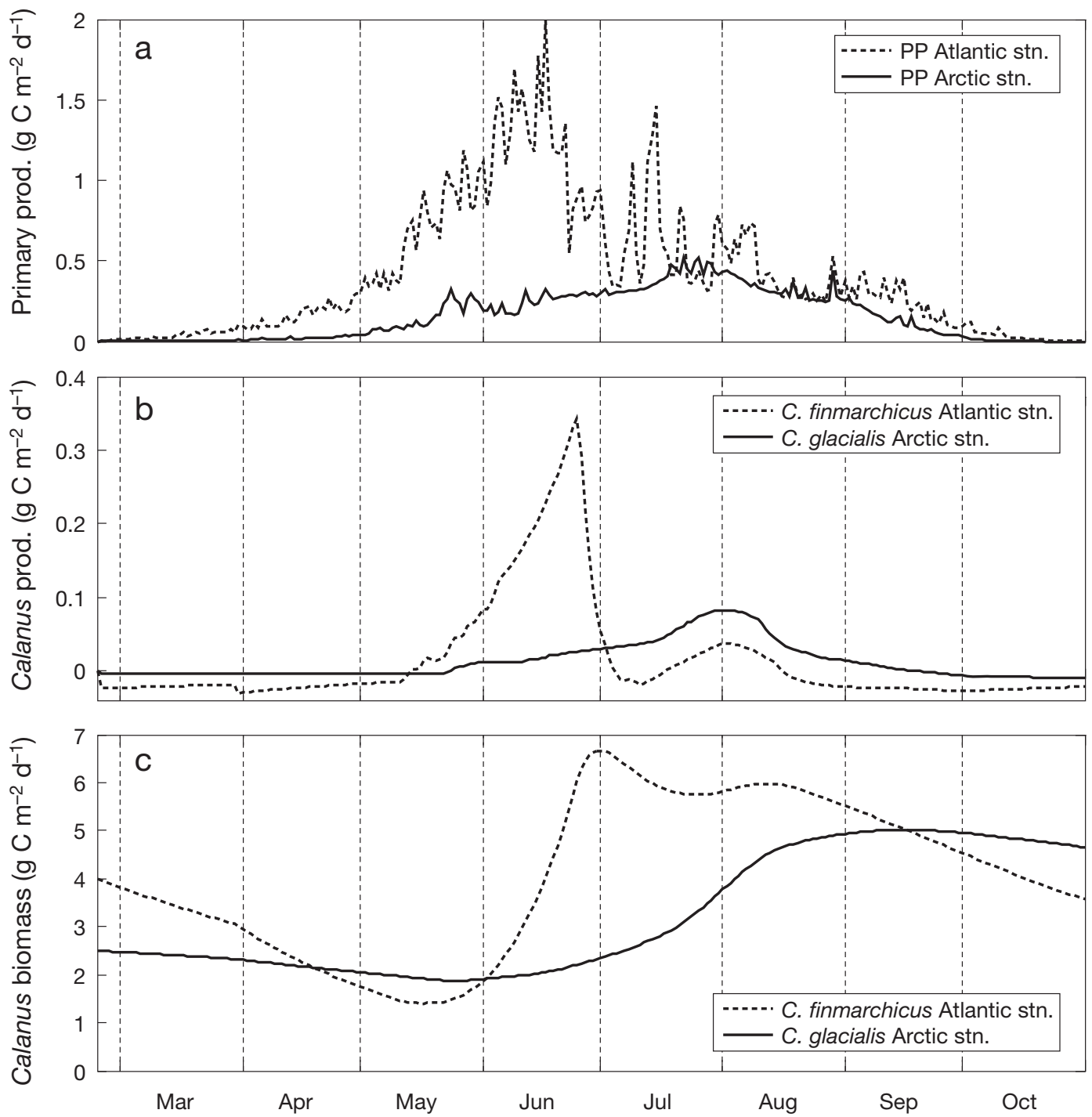

Fig. 5. Simulated (a) primary production (PP), (b) Calanus production, and (c) Calanus biomass versus time in the 2 grid cells (see Fig. 1) in the southern (Atlantic station) and northern (Arctic station) Barents Sea (1D simulation)

compared to $3.6 \mathrm{~g} \mathrm{C} \mathrm{m}^{-2}$ for the unperturbed case. The largest effect (least recovery) resulted from the biomass reduction of 1 July, which is at the seasonal maximum of biomass.

Scenarios of biomass reduction of Calanus glacialis between 1 June and 1 August also led to a few days' delay in the timing of peak production. These scenarios resulted in only a minor reduction in productivity, with the exception of the 1 August perturbation (Fig. 7). However, for all test cases C. glacialis biomass did not recover to the level of the unperturbed simulation. At the end of October, biomass ranged from 2.8 to $3.5 \mathrm{~g} \mathrm{C} \mathrm{m}^{-2}$, compared to $4.7 \mathrm{~g} \mathrm{C} \mathrm{m}^{-2}$ for the unperturbed case. The largest effect (least recovery) was seen for the biomass reduction of 1 August, which corresponds to the seasonal maximum of biomass.

\section{Variations in mortality rates}

To study how sensitive the model is to Calanus mortality parameterisation, 1D simulations were run with mortality rates set to $1.5,3$ and $4.8 \% \mathrm{~d}^{-1}$ and compared to the standard value of $0.75 \% \mathrm{~d}^{-1}$ in SINMOD. The values 3 and $4.8 \% \mathrm{~d}^{-1}$ represent our new field-based mortality rate estimates. For the mortality rates 1.5 and $3 \% \mathrm{~d}^{-1}$, the onset of peak production and biomass was delayed, and the magnitudes were reduced (Fig. 8). At the mortality rate of $3 \% \mathrm{~d}^{-1}$, the biomass never exceeded $2 \mathrm{~g} \mathrm{C} \mathrm{m}^{-2}$, which is less than $30 \%$ of the biomass at standard runs. At the mortality rate $4.8 \% \mathrm{~d}^{-1}$, the population collapsed. The model results with new field-based mortality estimates gave unrealistically low production and biomass values. We therefore per- 

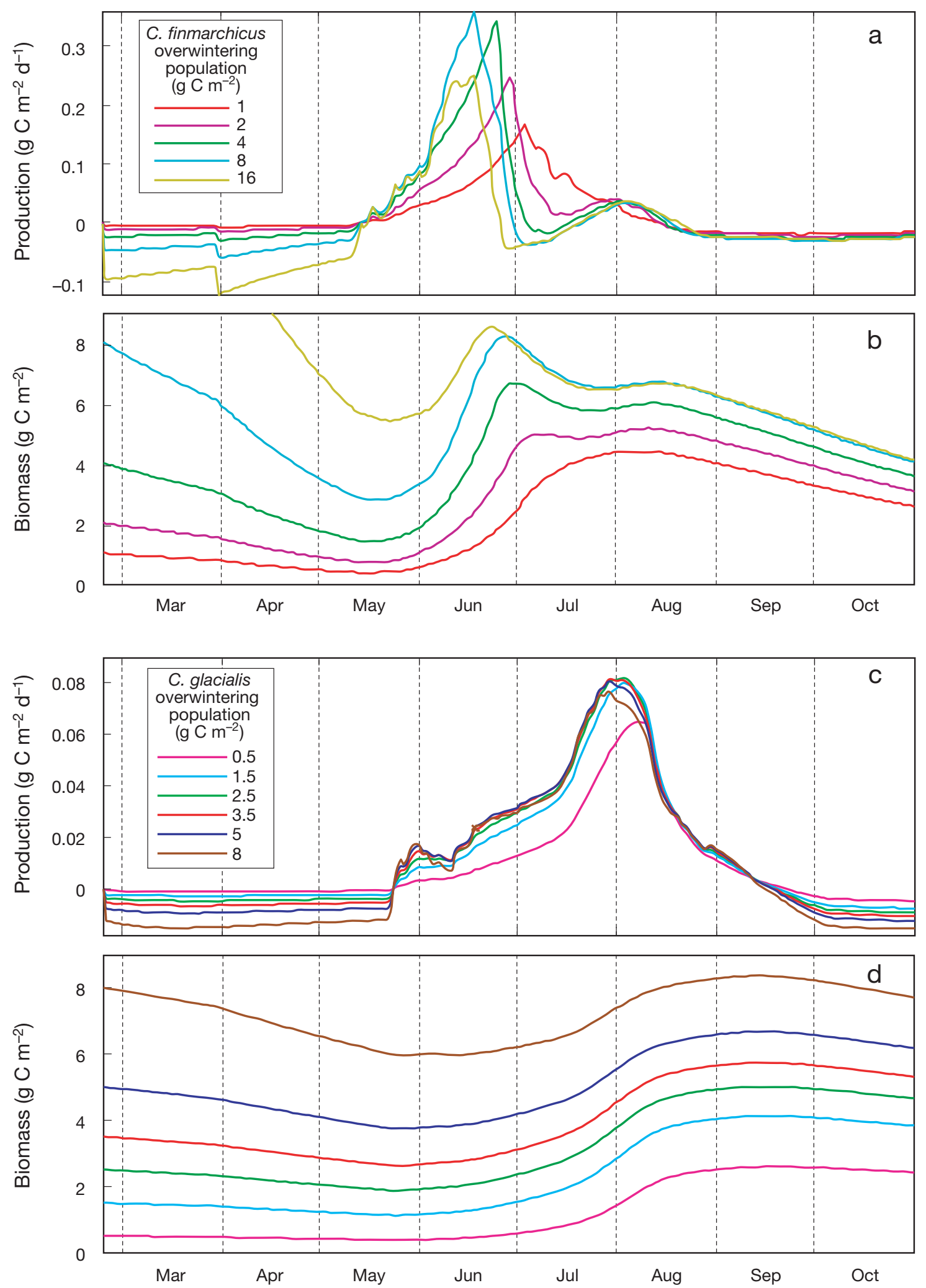

Fig. 6. Calanus spp. 1D simulations of Calanus production and biomass versus time in the grid cells in (a,b) the southern (Atlantic station, C. finmarchicus) and (c,d) the northern (Arctic station, C. glacialis) Barents Sea for different sizes of overwintering populations. The green curves represent the 'standard' model setup with overwintering populations of $4 \mathrm{~g} \mathrm{C} \mathrm{m}^{-2}$ for C. finnmarchicus and $2.5 \mathrm{~g} \mathrm{C} \mathrm{m}^{-2}$ for C. glacialis 

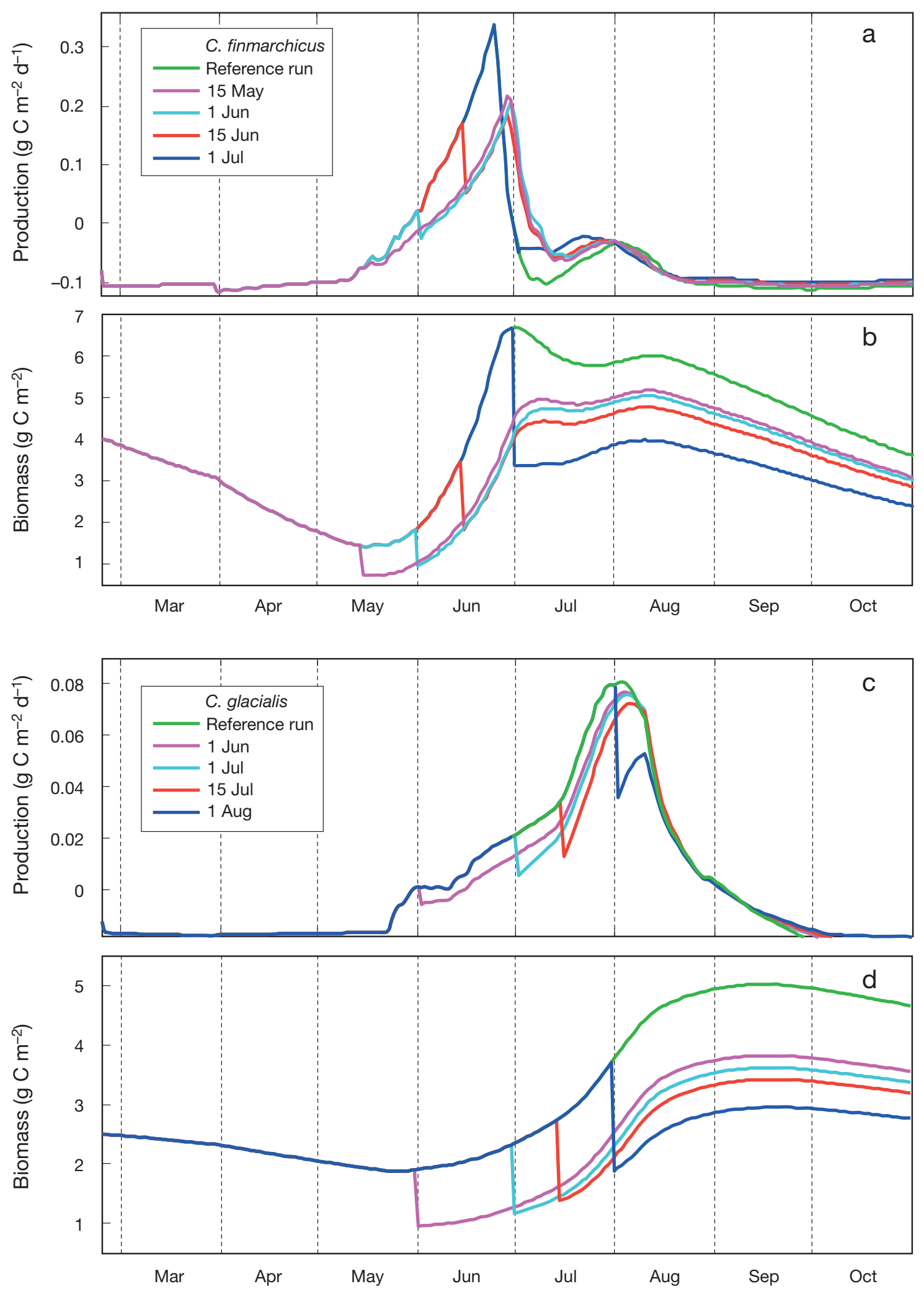

Fig. 7. Calanus spp. 1D simulations of Calanus production and biomass versus time in the grid cells in (a,b) the southern (Atlantic station, C. finmarchicus) and (c,d) the northern (Arctic station, C. glacialis) Barents Sea for sudden biomass reductions at 4 different time steps: C. finmarchicus biomass was reduced by $50 \%$ on 15 May, 1 June, 15 June and 1 July; C. glacialis biomass was reduced by $50 \%$ on 1 June, 1 July, 15 July and 1 August. The green curve in each panel represents the reference simulation without sudden biomass reductions 

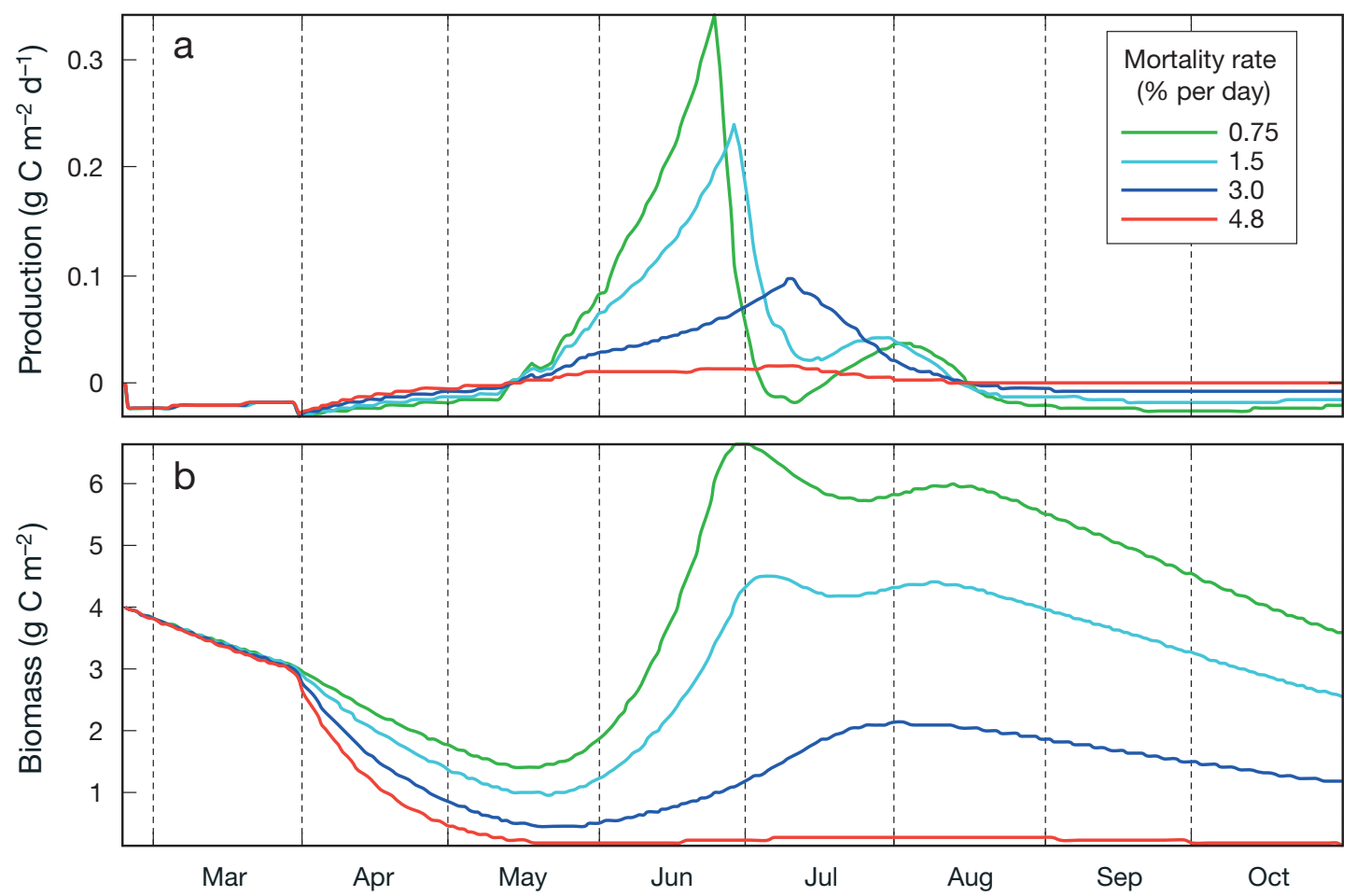

Fig. 8. Calanus finmarchicus. 1D simulations of (a) production and (b) biomass versus time in the grid cell in the southern Barents Sea (Atlantic Station) for different mortality rates. The green curve represents the simulation with standard mortality rate $\left(0.75 \% \mathrm{~d}^{-1}\right)$

formed a similar test where, in addition to an increased mortality rate $\left(3 \% \mathrm{~d}^{-1}\right)$, the growth rate was increased by $50 \%$, resulting in a higher production rate and biomass levels, with a peak biomass of $4 \mathrm{~g} \mathrm{C} \mathrm{m}^{-2}$ at the end of June (not shown).

\section{Spatio-temporal effects of increased mortality}

The 3D simulation of persistent high mortality resulted in a biomass reduction up to $55 \%\left(r_{B}>-0.55\right)$ at both locations (Figs. $9 \& 10$ ), but the size of the affected areas and the duration of the biomass reduction differed between the 2 locations. Both 'exposure areas' covered $1600 \mathrm{~km}^{2}(40 \times 40 \mathrm{~km})$, where $20 \%$ of the biomass was removed per day (mortality rate: $20 \% \mathrm{~d}^{-1}$ ) over a period of $35 \mathrm{~d}$.

After 20 d (20 May), the affected area on the Northern Norwegian shelf (in the Atlantic region) was 10 times the size of the exposure area, exhibiting biomass reductions of Calanus finmarchicus between 20 and $55 \%$ (Fig. 9). In contrast, the affected area east of Storbanken (in the Arctic region; C. glacialis) was 5 times the size of the exposure area (Fig. 10). On the Northern Norwegian shelf, the $C$. finmarchicus biomass reduction was distributed over the shelf and northwards, re- flecting the advection in this area. In August, 2 mo after the exposure ended, a biomass reduction of $10 \%$ was seen along the coast (Fig. 9, lower right panel), while a slightly increased biomass $(<2 \%)$ was observed farther afield.

The area east of Storbanken (Fig. 10) is characterised by less advection, and the effect was therefore limited to a smaller region, but with larger and more durable impacts. In September, 3 mo after the exposure ended, the biomass of Calanus glacialis had still not recovered, but was $20 \%$ lower than in the reference run.

\section{DISCUSSION}

Our analysis of field data and model simulations focused on mortality as a key parameter in understanding the population dynamics of Calanus finmarchicus and C. glacialis in the Barents Sea ecosystem. Our limited knowledge of natural mortality rates for these key copepod species, as well as spatial and temporal scales of variability in mortality rates, hinder our ability to quantitatively assess population-level impacts related to higher constant or episodic increases in mortality. This knowledge is essential in predicting ecological responses to stochastic perturbations such as 

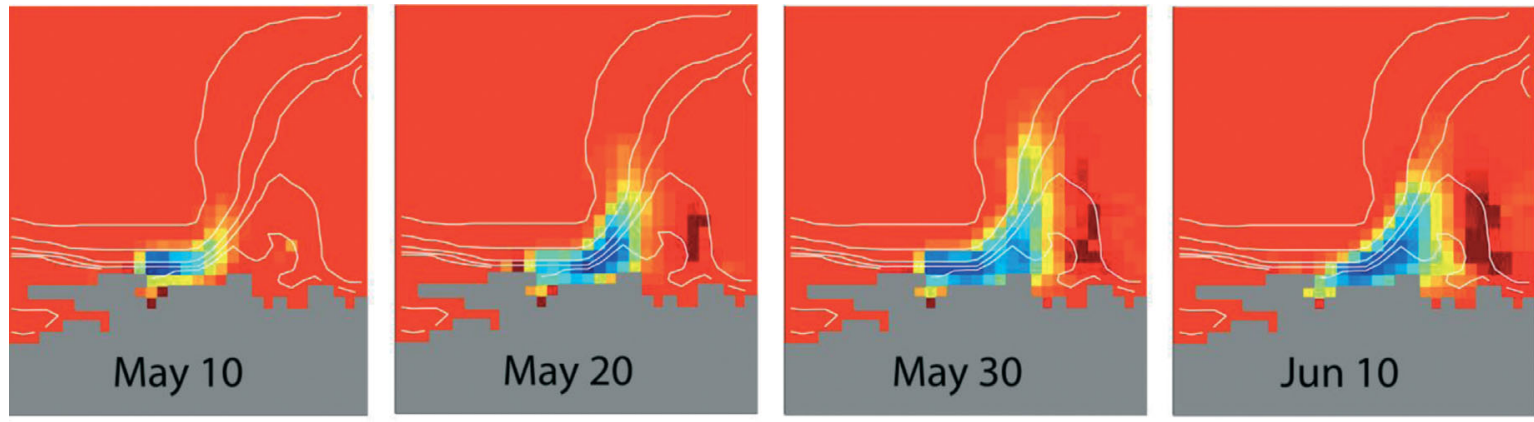

Change in biomass (\%)
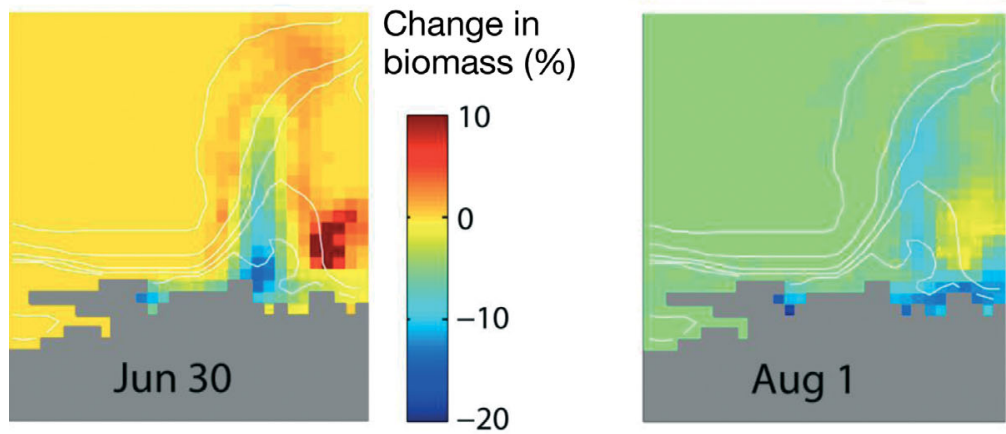

Change in biomass (\%) Fig. 9. Calanus finmarchicus. 3D
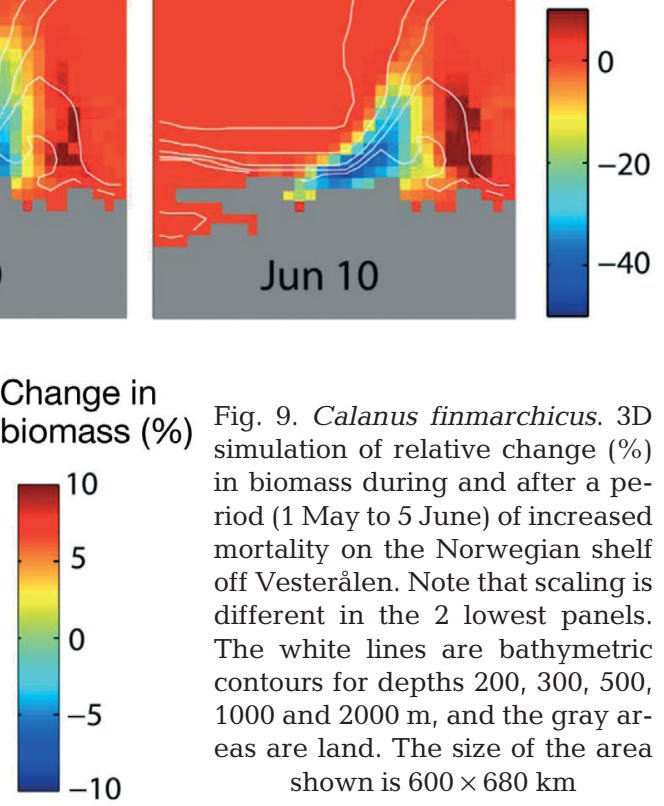
simulation of relative change $(\%)$ in biomass during and after a period (1 May to 5 June) of increased mortality on the Norwegian shelf off Vesterålen. Note that scaling is different in the 2 lowest panels. The white lines are bathymetric contours for depths 200,300,500, 1000 and $2000 \mathrm{~m}$, and the gray areas are land. The size of the area shown is $600 \times 680 \mathrm{~km}$
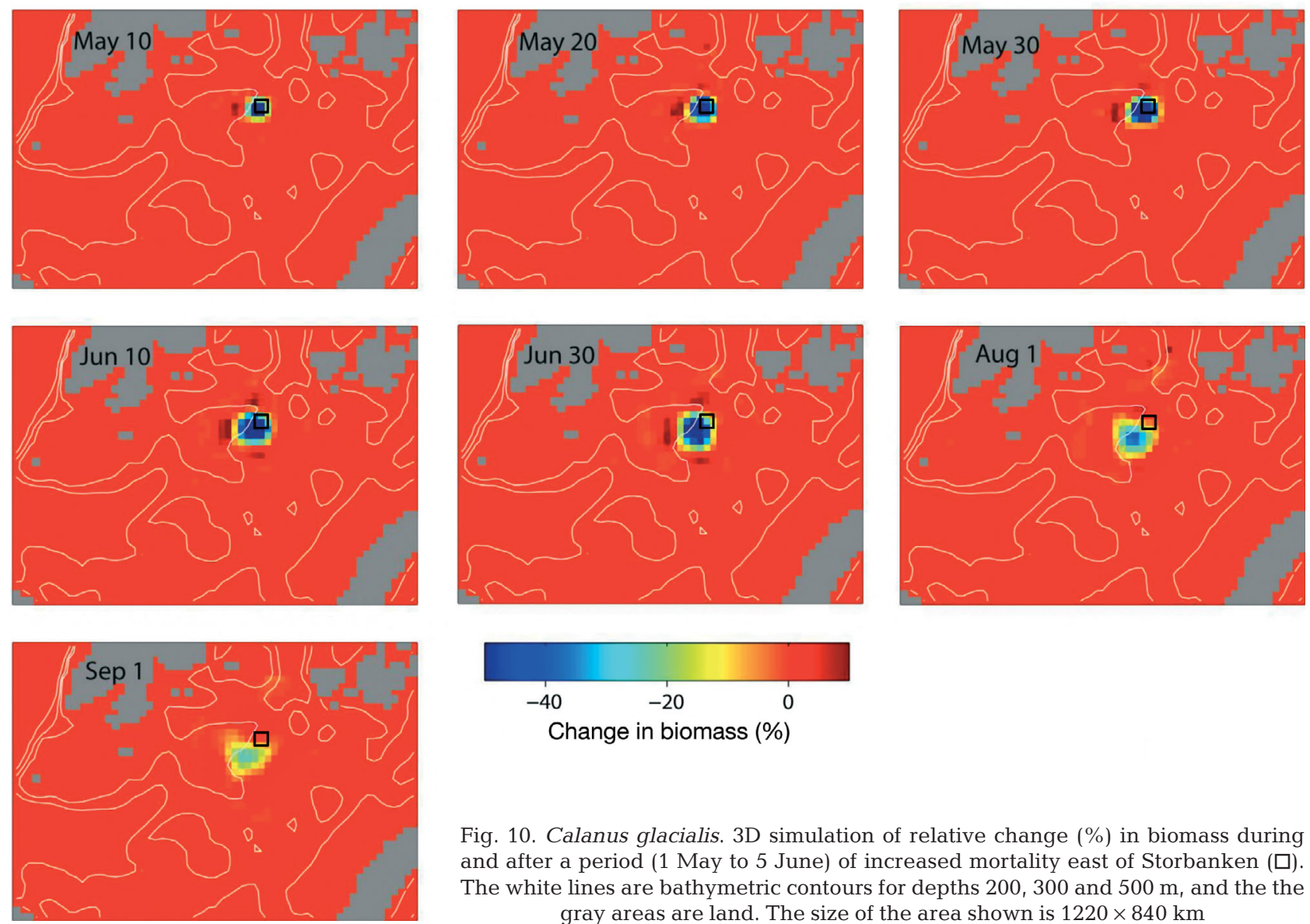

Fig. 10. Calanus glacialis. 3D simulation of relative change (\%) in biomass during and after a period ( 1 May to 5 June) of increased mortality east of Storbanken ( $\square$ ). The white lines are bathymetric contours for depths 200,300 and $500 \mathrm{~m}$, and the the gray areas are land. The size of the area shown is $1220 \times 840 \mathrm{~km}$ 
oil-spill events, as well as responses to long-term impacts such as climate change. The present results illustrate relationships between mortality, population development, and the responses of these variables to perturbation events. We found that species' differences in their response to changing mortality rates are linked to habitat and life-cycle characteristics of individual species. In particular, C. glacialis, with a 2 yr life cycle, has a more pronounced response to increases in mortality compared to $C$. finmarchicus, a species with a shorter lifespan (1 yr) and higher natural mortalities.

\section{Utility of model simulations}

Numerical models, such as the physical-biological coupled SINMOD, represent simplifications and numerical expressions of our knowledge of the physical system, the ecosystem, and their interactions. In the present study, we used a simplified 1D version of the model to evaluate the temporal response of Calanus to changed mortality rates. This approach focuses on the response of zooplankton to 1 induced change at a time. It allows us to evaluate species responses during 1 productive season at single locations, isolated from the more complex effects of advection. Advection has, however, a strong impact on the production of C. finmarchicus in the Barents Sea (Edvardsen et al. 2003). To get a more realistic simulation of both spatial and temporal effects of increased mortality of Calanus, 3D simulations are required. Our 3D simulation illustrates clearly how advection can both distribute an effect of a perturbation far away from the perturbation site, but also buffer the local effects on plankton in areas with high advective impact, like the Norwegian shelf and the southern Barents Sea. Our Arctic station represented a less advective region, leading to an enhanced local impact of increased mortality for C. glacialis.

To evaluate the realism in simulation results, comparisons with relevant field data are important. Such comparisons also evaluate the structure and key links in the ecosystem and test relationships between the ecosystem and the environment. New physical and biological data and parameterisations are continuously being incorporated into SINMOD to ensure that this model reflects our most recent ecosystem understanding (Ellingsen et al. 2008, 2009, Wassmann et al. 2010, Reigstad et al. 2011) and to ensure that the model is relevant for the domain of interest. This includes simulated model distributions of Calanus in the Barents Sea, compared to field data (Ellingsen et al. 2008). Models can test separate effects and handle complex interactions, and also serve as a guide to focus fieldwork investigations or experimental studies to sensitive parameters. With models, we can perform large- scale evaluation of patterns observed locally or processes identified through experimental investigation. In the present work, the use of 1D and 3D model setups identified mortality as 1 parameter in the ecosystem model that is sensitive to initial settings, and where sibling species such as the 2 Calanus species respond differently. Our estimates of natural mortality rates from field data, combined with model simulations using these values, point to a need for a better understanding not only on species' mortality rates, but also their growth rates.

\section{Field estimates of mortality rates}

Copepod mortality in nature exhibits considerable spatial and temporal heterogeneity (Ohman \& Wood 1996, Plourde et al. 2009). The data set used in the present investigation is not of a quality that enables such finely resolved estimates in time or space. However, our results indicate higher mortality in May through August, relative to the rest of the year, and a lower mortality rate in Calanus glacialis compared to C. finmarchicus in the unproductive season of the northern Barents Sea (Table 1). In the Northwestern Atlantic, $C$. finmarchicus stage-pair CV-CVI showed elevated mortality from June to December, while mortality patterns were more variable for other stage combinations and between locations (Plourde et al. 2009). Thus our data set, which contains estimates from several years and locations, may introduce biases caused by factors other than location and species (e.g. variability in predator regime; Eiane et al. 2002). Unfortunately, dataresolution issues for Calanus hinder investigations into the importance of mortality for secondary producers in the Barents Sea.

Our mortality estimates were based on the stage duration times provided by Campbell et al. (2001), which were based on experiments limited to temperatures $>4^{\circ} \mathrm{C}$. Some of our estimates, in particular those from the northeast Barents Sea, were obtained from waters of considerably lower temperature. In experimental situations at low temperatures, Corkett et al. (1986) reported stage durations of Calanus spp. somewhat lower than waht we have used. The implication from Eqs. (1) \& (2) is that we may have underestimated mortality for actively developing Calanus in coldwater stations, particularly in winter. However, as most of the populations tend to be in dormancy during this period (Conover 1988, Hirche \& Kwasniewski 1997, Arnkværn et al. 2005), the potential bias should be somewhat reduced, and we conclude that the differences in mortality between the 2 time periods probably largely reflect natural variability in the life history of Calanus spp. in the study area. 
The VLT data suggest that the major difference in mortality between the 2 Calanus species is found during winter. The data show a strong reduction in mortality for both species in winter, compared to summer, and the lowest winter mortality rate for C. glacialis. The ecological reasons for this are likely many. The switch from active feeding in the surface water with no pronounced vertical migration during the productive midnight-sun period (Falkenhaug et al. 1997, Arashkevich et al. 2002), to a predator-avoiding inactive diapause in a dark and deep habitat in the winter season, is part of the explanation behind the large difference in summer and winter mortality. Migrating predators like capelin or herring feeding on the lipid-rich C. finmarchicus in May and June (Varpe et al. 2005, Ellingsen et al. 2008) is another reason, and the stage composition in the population with dominance of young stages with higher mortality in summer, compared to older stages in winter, is a third factor.

\section{Species' biomass linked to overwintering population size}

The standard 1D simulations of biomass for the 2 Calanus species agree well with available studies on zooplankton dynamics in the Barents Sea (Tande 1991, Arashkevich et al. 2002, Ellingsen et al. 2008). The simulations reflect the well-known strong dependency of these species on the timing of the spring bloom, and the delayed seasonality at the Arctic station due to icecover postponing the spring bloom (Falk-Petersen et al. 2000, Hirche \& Kosobokova 2003).

Complementary 1D simulations compared the dependency of Calanus finmarchicus and C. glacialis production on different overwintering population sizes. While the size of the overwintering population strongly affects seasonal development of C. glacialis biomass, with prominent effects even at the end of the productive season, this was not the case for $C$. finmarchicus. This is mainly due to the lower growth rates of C. glacialis implemented in this simulation in order to balance populations over their predominantly 2 yr life cycle. Calanus shows high plasticity in life history throughout its distribution area, which spans several climatic zones (Tande 1991, Broms et al. 2009). In northern regions, C. finmarchicus usually overwinter as stage $\mathrm{CV}$ and reproduce as a response to the first feeding in the following spring (Tande 1991). As adults tend to die after reproduction, the adult mortality rate is high, and overwintering specimens are nearly entirely from the new generation. This species may thus be less affected by changes in the overwintering population size, as long as winter mortality is low and the reproductive success is sufficiently high during the next spring. Therefore, the initial large vari- ations in C. finmarchicus biomass converged towards the standard-run results by the end of these simulations. Food limitation for large populations and improved feeding conditions for small populations have most likely contributed to this response. In the Arctic and seasonally ice-covered shelf regions where C. glacialis is found, the productive season is so short that copepods usually require 2 yr to reach maturity. Overwintering C. glacialis populations therefore tend to consist of 2 age classes (typically developmental stages CIV and CV; Tande 1991, Kosobokova 1999, Broms et al. 2009), and the mortality rate is on average expected to be lower than for C. finmarchicus. This was also seen in the VLT data, where the winter mortality for C. glacialis was lower than for C. finmarchicus.

\section{Productivity cycles linked to mortality rates}

Simulation with variable overwintering population size not only influences biomass, but also the timing and maximum level of production rates. When we compared the 2 species' biomass responses, the productivity of Calanus glacialis showed a weaker response compared to C. finmarchicus. A loss in biomass in a C. glacialis population may be compensated by an increase in the the production rate. For C. finmarchicus, the lowest overwintering stock exhibited the longest delay (14 d) in the timing of maximum production and the lowest peak productivity rate $(<50 \%$ of the rate observed for the highest overwintering population simulation). We attribute this pattern to a reduced potential of the population to utilise the available food production at the optimal time. A delayed and reduced productivity peak was also seen when the Calanus populations were reduced by $50 \%$ at different time points of their productivity cycles. However, the timing of maximum productivity was similar for these tests, which we attribute to limited food availability in the model runs. When mortality was induced late in the productive cycle (1 July), production was not negatively affected. This may be due to improved feeding conditions relative to the standard run, a likely scenario also in nature (Tokle 2006). Copepod growth and reproduction requires high food quality, and their development is sensitive to the timing of algae production (Søreide et al. 2010). Algal production is regulated by light and nutrients, and a delayed Calanus growth or reduced grazing capacity can result in a mismatch between copepods and their food, with algal biomass sinking to the benthos (Carroll \& Carroll 2003, Reigstad et al. 2008) or being grazed by other herbivores if present. Therefore the same amount and quality of food may not be available later in the season, and the copepod population cannot compensate for early- 
season mortality losses. Similarly, a delay in the production and biomass peak of Calanus will have consequences for higher trophic-level species feeding on Calanus (Cushing 1990), such as cod and capelin (see e.g. Ellingsen et al. 2008). Such mechanisms are not resolved in the model at present.

A second major factor influencing Calanus spp. responses to changes in mortality is the impact of advection. A considerable fraction of the $C$. finmarchicus population overwinters at depth $(>700 \mathrm{~m})$ along the Norwegian Sea shelf slope and is advected into the Barents Sea every spring and then continuously through the productive season. Therefore, biomass production in the Barents Sea is continuously supported by this advective input (Edvardsen et al. 2003, Slagstad \& Tande 2007). C. glacialis overwinter on Arctic continental shelves, where there is no or limited advective supply to moderate the effects of increased local mortality during the growth season. The combination of differences in the life-cycle period and the role of advective supply in sustaining biomass greatly influences the response of these 2 Calanus species to increased mortality. Such differences are important to consider when evaluating species' responses to external perturbation events.

\section{Field-derived mortality rates versus model rates}

In general, mortality rates derived from field data of Calanus spp. indicate that rates vary throughout the season, depending on a number of factors, e.g. developmental stage, availability of food and predation (e.g. Eiane et al. 2002, Eiane \& Ohman 2004, Gislason et al. 2007). Our VLT-estimated mortality rates for $C$. finmarchicus (3.3 and $4.8 \% \mathrm{~d}^{-1}$ ) during summer are much higher than the rates currently used in the model $\left(0.75 \% \mathrm{~d}^{-1}\right)$. Our sensitivity analyses revealed that the mortality rate of $C$. finmarchicus strongly affects total $C$. finmarchicus production and biomass. Applying mortality rates of 3.0 and $4.8 \% \mathrm{~d}^{-1}$ in the model led to a drop in $C$. finmarchicus production of $60 \%$ and $>90 \%$ respectively, and a collapse in C. finmarchicus biomass. Based on these results, no corresponding tests were run for C. glacialis, because the difference between the default model mortality rate and the VLT-based mortality estimate was even higher for this species.

This may suggest that the upper limits to our field estimates of weight-specific mortality are erroneous. Unfortunately, besides the data used in the present investigation, there are few data on field mortality of Calanus in the Barents Sea that may serve as a source to validate our efforts, for instance to check for a bias in our conversion of individual-based rates into weight- based rates. Secondly, we have relied on estimates made from data from the latter part of the life cycle only (the copepodite stages), and extrapolating these estimates to cover the whole life cycle (eggs and nauplii) may be problematic. It is often assumed that mortality is very high in early life stages of broadcast spawning copepods (Ohman \& Hirche 2001, Hirst \& Kiørboe 2002), but this may vary over short spatial scales (Eiane et al. 2002). On the other hand, if the field mortality rates are correct, and the mortality rates presently used in the model are too low, then species' growth rates must also be too low, as the combination of mortality and growth rates in the model produce realistic biomasses that are comparable to observations over a large area and on inter-annual time scales (Ellingsen et al. 2008).

\section{Potential impacts of external perturbations on biomass and production}

The results of our simulations provide valuable information about key parameters of ecological relevance, which help to evaluate the outcome of external perturbations that may occur in northern marine ecosystems. Human activities are increasing in the region, particularly shipping of petroleum products (AMAP 2007, Bambulyak \& Frantzen 2009). Accidents in the past, such as the Exxon Valdez oil spill, have shown that the effects of an oil spill range from direct mortality of a limited number of individuals in an ecosystem to long-term effects leading to significant losses within a population (Peterson et al. 2003). The recent large blowout from the Deepwater Horizon oil rig in the Gulf of Mexico in 2010, which lasted $87 \mathrm{~d}$, produced an oil slick covering a surface area of about $41400 \mathrm{~km}^{2} 1 \mathrm{mo}$ after the accident (Cleveland 2010), and the ecological implications of the accident are only just being assessed. Compared to the Deepwater Horizon blowout, our model scenario can be regarded as small and conservative with its duration of $36 \mathrm{~d}$ and surface area of $1600 \mathrm{~km}^{2}$. Recent oil-drift simulations performed by the Norwegian Meteorological Institute (met. no) show that a large oil spill of duration $87 \mathrm{~d}$ on the Norwegian shelf of Vesterålen would affect the coastal waters from Lofoten to Nordkapp (M. Reistad, met. no, pers. comm.), thus greatly exceeding the area suggested in our simulation. It must be recognised that our 3D simulation evaluates a single arbitrary scenario of a constant mortality population loss. Our model experiment was performed to evaluate how biomass reductions propagate through space and time, without consideration of the influence of changes to the distribution, transport and degradation of oil; nor does the model take into account 
the true range of biological effects (Neff 2002, Peterson et al. 2003). Therefore, one must use caution when extrapolating our simulation results to 'realworld' cases. Instead, our simulations are meant to highlight a few key ecological interactions that sustain Calanus spp. populations in the Barents Sea and that would be expected to respond to a large-scale mortality event, irrespective of the cause. These key ecological interactions are discussed here with a view toward how the findings of the present study contribute to our understanding of population-level impacts of oil spills in northern marine ecosystems.

The responses to increased mortality for the 2 Calanus species, illustrated through 1D model simulations, are tightly linked to the life cycle of the individual species. For example, we have shown that a low overwintering population of C. glacialis leads to a lower population biomass during the following season. This implies that if the timing of an oil-spill event is such that it leads to reduced biomass in the overwintering population, we would expect a population reduction to occur in the following year. Similarly, if an oil spill occurs in a season following a naturally low overwintering population, C. glacialis would be at greater risk for a population loss. Conversely, the life cycle of $C$. finmarchicus makes this species more resilient at the population level to such perturbations, although the timing of production and biomass peak is likely to be affected, as shown in the 1D model simulations, with potential consequences for higher trophic levels like fish and seabirds feeding on the C. finmarchicus biomass.

Our 3D simulation illustrates how an oil spill leading to a mass-mortality event (20\% zooplankton biomass reduction for $36 \mathrm{~d}$ ) propagates in both space and time as a loss of biomass in Calanus spp. populations. The simulation resulted in a drop of zooplankton biomass from 5-6 $\mathrm{g} \mathrm{C} \mathrm{m}^{-2}$ (standard run) to $1-2 \mathrm{~g} \mathrm{C} \mathrm{m}^{-2}(20 \%$ $\mathrm{d}^{-1}$ mortality) during the critical summer-feeding period in the Arctic. The impact on the C. glacialis population (up to $55 \%$ population loss) at the Arctic station (Fig. 1) was relatively localised (Fig. 10), while a more widely distributed impact occurred for $C$. finmarchicus in the shelf area (Fig. 9). There was a significant drop in C. glacialis biomass during late May to early June (Fig. 10); by late August the area of influence moved somewhat to the southeast of the point of impact but a strong relative change in Calanus biomass is still visible. The size of the area of influence at each location is related to the predominant physical-oceanographic conditions, with a higher water-residence time at the location in Arctic waters compared to the Norwegian shelf area. Consequences for higher trophic levels will depend on a predator's ability (e.g. seabirds, capelin or cod larvae) to switch feeding grounds in the event of a significant reduction in Calanus biomass in one region. For nesting seabirds in particular, this may result in greater time and energy expenditures in food foraging for chicks, which over the long term may have consequences for breeding success (Kwasniewski et al. 2010).

\section{CONCLUSIONS}

The most important findings of the present study are: (1) The 2 sibling copepod species Calanus finmarchicus and C. glacialis respond differently to increased mortality and this can be explained by differences in their life cycle as well as habitat. (2) Increased mortality of Calanus influences the timing of peak Calanus production and biomass, with consequences for their ability to exploit the peak phytoplankton production. (3) Natural mortality rates presently used in the model may be too low, compared to new field estimates; combined investigations of natural mortality and growth rates are needed.

The present study also provides valuable insights into how models can be used as tools to identify critical parameters and to assess possible consequences of external forcing factors such as oil-spill events in the environment. The combination of using 1D models to identify and test sensitivity of critical parameters, and 3D physical-biologically coupled models to provide spatial effects through physical forcing, addresses 2 main issues that are crucial when trying to grasp ecosystem or key species responses. The importance of understanding life-history strategies and life cycles of species is also strongly underlined and exemplified through the responses from the 2 sibling species $C$. finmarchicus and C. glacialis. Modelling and sensitivity tests like those we have performed here can also help focus on the important questions in fieldwork to improve our knowledge of critical parameters.

Acknowledgements. This project was carried out within the 'Effects of Oil Spills in Pelagic Ecosystems (EOP)' project, which is a cooperation of the Institute of Marine Research (IMR); the Centre for Ecological and Evolutionary Synthesis (CEES), University of Oslo; and the ARCTOS network of marine ecologists (www.arctosresearch.net). Financial support for this research was provided by Norsk Hydro (now Statoil). We thank 4 anonymous reviewers for their constructive and helpful comments.

\section{LITERATURE CITED}

Aksnes DL, Ohman MD (1996) A vertical life table approach to zooplankton mortality estimation. Limnol Oceanogr 41: 1461-1469

Aksnes D, Miller CB, Ohman MD, Wood SN (1997) Estimation techniques used in studies of copepod population 
dynamics - a review of underlying assumptions. Sarsia 82:279-296

AMAP (Arctic Monitoring and Assessment Programme) (2007) Arctic oil and gas 2007. AMAP, Oslo. www.amap.no

> Arashkevich E, Wassmann P, Pasternak A, Wexels Riser C (2002) Seasonal and spatial changes in biomass, structure, and development progress of the zooplankton community in the Barents Sea. J Mar Syst 38:125-145

Arnkværn G, Daase M, Eiane K (2005) Dynamics of coexisting Calanus finmarchicus, C. glacialis and C. hyperboreus populations in a high arctic fjord. Polar Biol 28:528-538

Bambulyak A, Frantzen B (2009) Oil transport from the Russian part of the Barents Region. Status per January 2009. The Norwegian Barents Secretariat and Akvaplan-niva, Kirkenes

Basedow SL, Edvardsen A, Tande KS (2008) Vertical segregation of Calanus finmarchicus copepodites during the spring bloom. J Mar Syst 70:21-32

Broms C, Melle W, Kaartvedt S (2009) Oceanic distribution and life cycle of Calanus species in the Norwegian Sea and adjacent waters. Deep-Sea Res II 56:1910-1921

Calbet A, Saiz E (2005) The ciliate-copepod link in marine ecosystems. Aquat Microb Ecol 38:157-167

Campbell RG, Wagner MM, Teegarden GJ, Boundreau CA, Durbin EG (2001) Growth and development rates of the copepod Calanus finmarchicus reared in the laboratory. Mar Ecol Prog Ser 221:161-183

Carroll ML, Carroll J (2003) The Arctic seas. In: Black KD, Shimmield GB (eds) Biogeochemistry of marine systems. Blackwell Publishing, Oxford, p 127-156

> Chapman PM, Riddle MJ (2003) Missing and needed: polar marine ecotoxicology. Mar Pollut Bull 46:927-928

Cleveland CJ (2010) Deepwater Horizon oil spill. In: The encyclopedia of earth. www.eoearth.org/article/Deepwater Horizon_oil_spill

Conover RJ (1988) Comparative life histories in the genera Calanus and Neocalanus in high latitudes of the northern hemisphere. Hydrobiologia 167-168:127-142

Corkett CJ, McLaren IA, Sevigny JM (1986) The rearing of the marine calanoid copepods Calanus finmarchicus (Gunnerus), C. glacialis Jashnov, and C. hyperboreus Krøyer, with comment on the equiproportional rule. In: Schriver G, Schminke HK, Shih CT (eds) Syllogeus 58. Proc 2nd Int Conf Copepoda, 13-17 August. National Museum of Canada, Ottawa, p 539-546

$>$ Cushing DH (1990) Plankton production and year-class strength in fish populations: an update of the match mismatch hypothesis. Adv Mar Biol 26:249-293

> Daase M, Eiane K (2007) Mesozooplankton distribution in northern Svalbard waters in relation to hydrography. Polar Biol 30:969-981

> Daase M, Vik JO, Bagøien E, Stenseth NC, Eiane K (2007) The impact of advection Calanus near Svalbard: statistical relations between salinity, temperature and copepod abundance. J Plankton Res 29:903-911

> Dalpadado P, Ingvaldsen R, Hassel A (2003) Zooplankton biomass variation in relation to climatic conditions in the Barents Sea. Polar Biol 26:233-241

Edvardsen A, Tande KS, Slagstad D (2003) The importance of advection on production of Calanus finmarchicus in the Atlantic part of the Barents Sea. Sarsia 88:261-273

- Eiane K, Ohman MD (2004) Stage-specific mortality of Calanus finmarchicus, Pseudocalanus elongatus and Oithona similis on Fladen Ground, North Sea, during a spring bloom. Mar Ecol Prog Ser 268:183-193

- Eiane K, Asknes DL, Ohman MD, Wood S, Martinussen MB (2002) Stage-specific mortality of Calanus spp. under dif- ferent predation regimes. Limnol Oceanogr 47:636-645

Ellingsen I, Dalpadado P, Slagstad D, Loeng H (2008) Impact of climatic change on the biological production in the Barents Sea. Clim Change 87:155-175

- Ellingsen I, Slagstad D, Sundfjord A (2009) Modification of water masses in the Barents Sea and its coupling to ice dynamics: a model study. Ocean Dyn 59:1095-1108

Falk-Petersen S, Hopkins CCE, Sargent JR (1990) Trophic relationships in the pelagic, arctic food web. In: Barnes M, Gibson RN (eds) Proc 24th Eur Mar Biol Symp, Oban, 4-10 Oct 1989. Aberdeen University Press, Aberdeen, p 315-333

Falk-Petersen S, Pedersen G, Kwasniewski S, Hegseth EN, Hop H (1999) Spatial distribution and life-cycle timing of zooplankton in the marginal ice zone of the Barents Sea during the summer melt season in 1995. J Plankton Res 21: 1249-1264

Falk-Petersen S, Hop H, Budgell WP, Hegseth EN and others (2000) Physical and ecological processes in the marginal ice zone of the northern Barents Sea during the summer melt period. J Mar Syst 27:131-159

Falk-Petersen S, Mayzaud P, Kattner G, Sargent JR (2009) Lipids and life strategy of Arctic Calanus. Mar Biol Res 5: $18-39$

Falkenhaug T, Tande KS, Semenova T (1997) Diel, seasonal and onthogenetic variations in the vertical distributions of four marine copepods. Mar Ecol Prog Ser 149:105-119

> Fossheim M, Primicerio R (2008) Habitat choice by marine zooplankton in a high-latitude ecosystem. Mar Ecol Prog Ser 364:47-56

- Gislason A, Eiane K, Reynisson P (2007) Vertical distribution and mortality of Calanus finmarchicus during overwintering in oceanic waters southwest of Iceland. Mar Biol 150: $1253-1263$

> Halvorsen E, Tande KS, Edvardsen A (2003) Habitat selection of overwintering Calanus finmarchicus in the NE Norwegian Sea and shelf waters off Northern Norway in 200002. Fish Oceanogr 12:339-351

> Hirche HJ, Kosobokova K (2003) Early reproduction and development of dominant calanoid copepods in the sea ice zone of the Barents Sea-need for a change of paradigms? Mar Biol 143:769-781

Hirche HJ, Kwasniewski S (1997) Distribution, reproduction and development of Calanus species in the Northeast Water in relation to environmental conditions. J Mar Syst 10:299-317

Hirst AG, Kiørboe T (2002) Mortality of marine planktonic copepods: global rates and patterns. Mar Ecol Prog Ser 230:195-209

Holling CS (1959) Some characteristics of simple type of predation and parasitism. Can Entomol 91:385-398

Kaartvedt S (1996) Habitat preferences during overwintering and timing of seasonal vertical migration of Calanus finmarchicus. Ophelia 44:145-156

> Kosobokova KN (1999) The reproductive cycle and life history of the Arctic copepod Calanus glacialis in the White Sea. Polar Biol 22:254-263

- Kwasniewski S, Gluchowska M, Jakubas D, WojczulanisJakubas K and others (2010) The impact of different hydrographic conditions and zooplankton communities on provisioning little auks along the west coast of Spitsbergen. Prog Oceanogr 87:72-82

Loeng $\mathrm{H}$ (1991) Features of the physical oceanographic conditions of the Barents Sea. Polar Res 10:5-18

Mann KH, Lazier JRN (2006) Dynamics of marine ecosystems: biological-physical interactions in the oceans, 3rd edn. Blackwell Publishing, Malden

Mauchline J (1998) The biology of calanoid copepods. Adv 
Mar Biol 33. Academic Press, London

Mullin MM, Brooks ER (1970) Production of the planktonic copepod Calanus helgolandicus. Bull Scripps Inst Oceanogr $17: 89-103$

Neff JM (2002) Bioaccumulation in marine organisms. Effects of contaminants from oil well produced water. Elsevier Science Publishers, Amsterdam

Ohman MD, Hirche HJ (2001) Density-dependent mortality in an oceanic copepod population. Nature 412:638-641

Ohman MD, Wood SN (1996) Mortality estimation for planktonic copepods: Pseudocalanus newmani in a temperate fjord. Limnol Oceanogr 41:126-135

Østvedt OJ (1955) Zooplankton investigations from weather ship M in the Norwegian Sea, 1948-1949. Hvalrådets Skr 40:1-93

$>$ Peterson CH, Rice SD, Short JW, Esler D, Bodkin JL, Ballachey BE, Irons DB (2003) Long-term ecosystem response to the Exxon Valdez oil spill. Science 302:2082-2086

Plourde SP, Pepin P, Head EJH (2009) Long-term seasonal and spatial patterns in mortality and survival of Calanus finmarchicus across the Atlantic Zone Monitoring Programme region, Northwest Atlantic. ICES J Mar Sci 66: 1942-1959

Reigstad M, Wexels Riser C, Wassmann P, Ratkova T (2008) Vertical export of particulate organic carbon: attenuation, composition and loss rates in the northern Barents Sea. Deep-Sea Res II 55:2308-2319

Reigstad M, Carroll J, Slagstad D, Ellingsen I, Wassmann P (2011) Intra-regional comparison of productivity, carbon flux and ecosystem composition within the northern Barents Sea. Prog Oceanogr (in press) doi:10.1016/ j.pocean.2011.02.005

Sakshaug E, Slagstad D (1992) Sea ice and wind: effects on primary productivity in the Barents Sea. Atmos-Ocean 30:579-591

Scott CL, Kwasniewski S, Falk-Petersen S, Sargent JR (2000) Lipids and life strategies of Calanus finmarchicus, Calanus glacialis and Calanus hyperboreus in late autumn, Kongsfjorden, Svalbard. Polar Biol 23:510-516

Skarðhamar J, Svendsen E (2005) Circulation and shelf-ocean interaction off North Norway. Cont Shelf Res 25:1541-1560

Slagstad D (1987) A 4-dimentional physical model of the Bar-

Editorial responsibility: Matthias Seaman,

Oldendorf/Luhe, Germany ents Sea. SINTEF report STF48 F87013. SINTEF, Trondheim

Slagstad D, McClimans TA (2005) Modelling the ecosystem dynamics of the Barents Sea including the marginal ice zone: I. Physical and chemical oceanography. J Mar Syst 58:1-18

Slagstad D, Tande K (2007) Structure and resilience of overwintering habitats of Calanus finmarchicus in the Eastern Norwegian Sea. Deep-Sea Res II 54:2702-2715

Slagstad D, Tande KS, Wassmann P (1999) Modelled carbon fluxes as validated by field data on the north Norwegian shelf during the productive period in 1994. Sarsia 84:303-317

Søreide J, Leu E, Berge J, Graeve M, Falk-Petersen S (2010) Timing of blooms, algal food quality and Calanus glacialis reproduction and growth in a changing Arctic. Glob Change Biol 16: 3154-3163

Sundfjord A, Ellingsen I, Slagstad D, Svendsen H (2008) Vertical mixing in the marginal ice zone of the northern Barents Sea - results from numerical model experiments. DeepSea Res II 55:2154-2168

Tande KS (1991) Calanus in north Norwegian fjords and in the Barents Sea. Polar Res 10:389-407

Tokle NE (2006) Are the ubiquitous marine copepods limited by food or predation? Experimental and field-based studies with main focus on Calanus finmarchicus. PhD thesis, Norwegian University of Science and Technology, Trondheim

Varpe $\varnothing$, Fiksen $\varnothing$, Slotte A (2005) Meta-ecosystems and biological energy transport from ocean to coast: the ecological importance of herring migration. Oecologia 146: 443-451

> Wassmann P, Slagstad D (1993) Seasonal and annual dynamics of particulate carbon flux in the Barents Sea. Polar Biol 13:363-372

Wassmann P, Slagstad D, Wexels Riser C, Reigstad M (2006) Modelling the ecosystem dynamics of the Barents Sea including the marginal ice zone II. Carbon flux and interannual variability. J Mar Syst 59:1-24

> Wassmann P, Slagstad D, Ellingsen I (2010) Primary production and climatic variability in the European sector of the Arctic Ocean prior to 2007: preliminary results. Polar Biol 33:1641-1650

Submitted: February 8, 2010; Accepted: January 14, 2011 Proofs received from author(s): April 4, 2011 